\title{
Sustainable health region development from the perspective of system theory - an empirical cross-regional case study ${ }^{1}$
}

\author{
Michael Volgger \\ Institute for Regional Development and Location Management \\ European Academy of Bozen-Bolzano (EURAC research) \\ Address: Drususallee 1/VialeDruso 1, 39100 Bozen/Bolzano, Italy \\ Email: michael.volgger@eurac.edu \\ Phone: +390471 055325 \\ Fax: +390471055429 \\ (corresponding author) \\ Tomas Mainil \\ $1^{\text {st }}$ institutional affiliation: \\ Capacity group Health, Governance and Transnationalism \\ HZ University of Applied Sciences \\ Address: Edisonweg 4, Vlissingen, Netherlands \\ Email: Main0003@hz.nl \\ $2^{\text {nd }}$ institutional affiliation: \\ NHTV Breda University of Applied Sciences \\ Address: Mgr. Hopmanstraat 1, 4817 JT Breda, Netherlands \\ Email: mainil.t@nhtv.nl
}

${ }^{1}$ This is an author generated postprint version (with author's formatting) of the article:

Volgger, M., Mainil, T., Pechlaner, H., \& Mitas, O. (2015). Health region development from the perspective of system theory-An empirical cross-regional case study. Social Science \& Medicine, 124, 321-330.

The final publication is available at: http://doi.org/10.1016/j.socscimed.2014.05.004

(C) 2014. This manuscript version is made available under the CC-BY-NC-ND 4.0 license http://creativecommons.org/licenses/by-nc-nd/4.0/ 


\author{
Harald Pechlaner \\ $1^{\text {st }}$ institutional affiliation:
}

Institute for Regional Development and Location Management

European Academy of Bozen-Bolzano (EURAC research)

Address: Drususallee 1/Viale Druso 1, 39100 Bozen/Bolzano, Italy

Email: harald.pechlaner@eurac.edu

Phone: +390471 055420

Fax: +390471055429

$2^{\text {nd }}$ institutional affiliation:

Chair in Tourism

Catholic University of Eichstätt-Ingolstadt

Address: Pater-Philipp-Jeningen-Platz 2, 85072 Eichstätt, Germany

Email: harald.pechlaner@ku-eichstaett.de

\title{
Ondrej Mitas
}

Academy for Tourism

NHTV Breda University of Applied Sciences, Netherlands.

Address: Mgr. Hopmansstraat 1, 4817 JT Breda, Netherlands

Email: ondrejmitas@gmail.com 


\title{
Sustainable health region development from the perspective of system theory - an empirical cross- regional case study
}

\begin{abstract}
:
Governments are increasingly establishing health regions as a means to deal with current challenges of public health service. These regions are seen as instruments to balance public and private stakeholders, and offer health care to regional citizens as well as to medical/health tourists. However, it is still unclear how the development of such health regions as well as their governance may be conceptualized. We apply Luhmann's system theory approach in the context of a cross-regional case study that compares health region developments in the Autonomous Province of Bolzano-South Tyrol (Italy) and in the province of Zeeland (the Netherlands). We suggest that Luhmann's system theory provides a useful set of criteria to evaluate and judge health region development. Fully developed health regions can be understood as auto-poietic systems. By emphasizing programs, personnel, and communication channels, these case studies illustrate the suitability of the system theory toolset to analyze the governance and spatial embeddedness of health regions. Additionally, the study contributes to literature by indicating that health regions are closely related to identity issues and to decision making in regions.
\end{abstract}

Keywords: health region, system theory, governance, cross-border health care, medical tourism, health tourism, Zeeland, South Tyrol

\section{Highlights:}

- We explore the applicability of system theory to health region development.

- Health region governance depends on programs, personnel and communication channels.

- We compare the two European regions of Zeeland and South Tyrol/Bolzano.

- Health regions appear as mechanisms in identity politics. 


\section{Introduction}

Regions have been related to health in the past. The World Health Organization (WHO) Regions for Health initiative illustrates this movement (WHO, 2008). However, governments have more recently been pursuing the development of health regions, often in close connection with medical tourism (Connell, 2006) and trade in health services (Smith, Chanda, \& Tangcharoensathien, 2009). Specifically, in the ASEAN region, Singapore, Thailand, Malaysia have been forerunners in developing hubs with dedicated medical expertise and manpower (Pocock \& Hong Phua, 2011; Whittaker, 2008) focused on the attraction of international patients. Furthermore, in the European Union (EU), some countries and regions have shown increased interest towards international patients, though less explicitly. For instance, the regions of Bavaria (Bavarian State Ministry of the Environment and Public Health, 2014) and Nord Rhine-Westphalia (Tourismus NRW e.V., 2014) in Germany are focusing on health region development. Likewise, Belgium is receiving notable numbers of international patients, but would like to monitor and manage these arrivals (Jaarverslag Observatorium Patiëntenmobiliteit, 2012). Furthermore, the EU is known as a region with several cross-border health care activities between border hospitals (Glinos \& Wismar, 2013).

Advancing this understanding, we suggest that a health region is an answer to some of the challenges posed by the liberalization and internationalization of demand in health care. As in other fields, the internationalization of demand makes it necessary to rethink localized supply but does not replace it (see Wiener, 1999). Indeed, the notion of a health region underscores the territorial dimension in the governance of healthcare offerings and thus can help to localize them in governable territorial units. However, it is important to note that the territorial anchorage of a health region does not necessarily need to follow previously existing administrative borders and thus can implement a transnational dimension where useful. Criteria for the establishment of health regions might be rather functional ones, such as shares in common values, competencies, offers and common target groups in the area of health services in order to generate synergies, with particular regard to promoting health tourism. We consider the health region as an instrument suitable both in health management and destination management, capable of ensuring public and private health as well as tourism related goals.

Thus, a health region may be considered a means to achieve the objective of increasing both effectiveness and efficiency of health service delivery to residents and international guests - in a globalized environment. 
It is possible to differentiate at least two general situations in health region development:

a. A development of health regions that follows existing territorial boundaries, e.g. with an existing territorial - regional - subdivision of health service management. The health region of Bavaria could be perceived as such (Bavarian State Ministry of the Environment and Public Health, 2014), but also the public health region systems of Canada and Italy serve as cases.

b. A development of health regions that includes overcoming established boundaries (i.e. developing new health regions), which may mean Installing a cross-national, trans-boundary health region. Earlier EU good practices include the Euregios (Brand et al., 2008), or on a larger scale, the Baltic see health region (ScanBalt BioRegion, 2014).

First, the case study of the region of Zeeland is an example of (a). It does not challenge the territorial boundaries of its province, but wants to make a linkage between the health of its citizens, health related products/services and its landscape; secondly, the case of South-Tyrol with the "Eastern Dolomites health region" is an example of (b) that includes an idea of overcoming or re-arranging territorial borders in the health area. As the processes in these both regions concern initial phases, they are helpful in highlighting major challenges in developing a health region.

The objective of this paper is to explore to what extent system theory can inform health region development. We suggest that Luhmann's system theory toolbox can help to judge the stage of development of such a health region. Under this perspective, a fully developed health region would be characterized by involving a broad range of stakeholders and offering benefits to them. It would include visualization and marketing of the health region, a specific organizational structure with program and personnel as well as specific internal and external communication channels. Provided that these assumptions concerning the ideal state of a health region are in order, the main question would be: Can health regions be auto-poietic and self-regulating, and if so, how and under what conditions?

Luhmann's system theory (Luhmann, 1992, 2000; Seidl, 2004) refers to several types of social systems that may be auto-poietic. According to Luhmann (1992), systems are auto-poietic when they selfreproduce. Elements within an auto-poietic system reproduce other elements in the system, perpetuating the system as a whole. According to Luhmann (Luhmann, 1992, 2000; Seidl, 2004; Seidl \& Becker, 2006), decisions are the core of an organization conceived as a social system. Nassehi (2005) depicts organizations even as 'decision machines'. Relating this notion to a health region, stakeholders 
within that region may define a shared decision set, in which they jointly decide and take actions. These actions are ideally formulated in a constellation of public and private members, representing public health goals and the economic goals of the region. Additionally, Luhmann identifies 'decision premises' in organizations, including programs, personnel and communication channels (Seidl, 2004). For example, the Malaysian and Bavarian governments have both issued programs to proactively develop into health regions. Normally, personnel are hired to implement these programs and communication channels play an important role within organizational structures such as a health region. The Bavarian ministry has applied cluster management in setting up meetings between different stakeholders in the context of the health region, opening new communication channels between these parties (Mainil et al., 2013).

We chose to use the theoretical framework of Luhmann for three reasons. First, Luhmann's argument to centralize the 'decision' as the core of the organization is useful to explain the concept of a health region, as several strategic decision steps need to be taken into account by multiple actors to instigate such a development. Second, other organizational theories such as that of post-bureaucratic organization design (characterized by flexible structures, continuous improvement, networking, a market orientation, decentralization, self-management and organizational learning) and cooperativism (with open and voluntary membership, democratic forms of control, labor hires capital mechanisms and social awareness) (Luhman and Cunliffe, 2013; Courpasson and Clegg, 2006; Webb, 2004 in Luhman and Cunliffe, 2013) are more likely to apply to health regions in further stages of development. Thus, we assume that these theories can supplement rather than supplant Luhmann's concepts.

\section{Literature review}

The present study conceptualizes a health region as a social system. Luhmann's system theory is applied to health regions, which means conceiving these health regions as social systems. The health system of a country may be seen as a social system, recently opened by the inflow of international patients. International patient flows are alternately seen as threats for national health systems or chances to optimize and globalize these systems along as well as promoting a European health agenda (Mainil et al., 2013; Martimianakis \& Hafferty, 2013; Ormond, 2013).

Luhmann (Luhmann, 1992, 2000; Seidl, 2004) underscores the relevance of decision making in such social systems, which leads to an appraisal of decision premises, including programs, personnel and communication channels. The value of this conceptual framework lies in its ability to highlight 
connections between related discussions about development of sustainable health regions. Amongst others, stakeholder theory, ethical theory and visualization theory offer a number of shared preoccupations and research objectives (see Fig. 1).

$$
<\text { Insert here Figure 1> }
$$

\subsection{Health regions}

There is a clear distinction in what is conceived as a medical hub in the ASEAN region (Pocock \& Phua, 2011) and the rationale of an organization such as the WHO Regions for Health Network (Anon., 2008). For ASEAN, health care is seen as an economic growth engine for contributing to the GDP of a country, resulting in the development of private-public partnerships (PPP's), such as in South-Korea, with the Korea International Medical Association. For the WHO, health is related to public governance to secure health goals for European populations in the framework of a region. In the EU, border regions are environments of development (e.g., Euregios/Euroregions; Brand, Hollederer, Wolf, \& Brand, 2008), patients mobility (Glinos et al., 2010), professional mobility, (Glinos, 2012), and cooperation between hospitals (Glinos \& Wismar, 2013). Bi-lateral agreements between nation states could also be seen as an opportunity for sustainable medical tourism and regional development (Martinez-Alvarez, 2011; Volgger, Pechlaner, \& Pforr, 2013). Most literature on the relation between health and regions is focused on case studies about treatment processes in one particular region or country. Other authors discuss the communication and marketing of territorial areas for medical tourism purposes (see e.g. Crooks, Turner, Snyder, Johnston, \& Kingsbury, 2011). A focus on governance related to the steering process of a transnational health region (Mainil et al., 2013) is recent and still underdeveloped in academic health systems research.

Pforr, Pechlaner, Locher, and Jochmann (2011) suggest that important factors in health region development include research, education, health prevention within companies, medical technology, hospitals, specialized primary health care providers, and health tourism. Mainil, Dinnie, Botterill, Platenkamp, van Loon, and Meulemans (2013) suggest that sustainable health region development requires a constructive combination of public and private stakeholders guarded by a strong regional government with a focus on public health goals. This development approach must include a policy with thorough ethical management that balances the various aims and target groups involved. More specifically, Mainil et al. (2013) assert that the local population needs to benefit this health region 
development, that the health region should be portrayed in a truthful manner, and that health regions should themselves be situated in networks of regions, each with their own character and thus able to mutually balance strengths and weaknesses. For example, the EU directive on patient rights (NHS European Office, 2011) urges nation states to pro-actively promote patient mobility by installing information points for international patients. Such information points could form a communicative network where multiple health regions list their medical specialties and expertise.

\subsection{Organizations as social systems}

Schoeneborn (2011) indicated that applications of Luhmann's work on organization theory in Englishlanguage publications has only recently begun to grow. He elaborates on Luhmann's communication in organizations based on decisions, asserting that "in line with his general theoretical framework, he Luhmann - conceptualizes decision not as a mental operation, but as a specific form of communication" (Schoeneborn, 2011, p. 671). Schoeneborn (2011, p.682 ) asked "how organizations ensure their perpetuation, though they are based on something as ephemeral as communication" as an issue for further research. This issue could be translated to health region development, addressing the challenge of keeping decision communications functioning in a health region program.

In line with Luhmann, Sels (1997) suggested that organizations are systems of membership. This means that for health regions to be conceived as organizations, stakeholders should be part of such health regions in a fixed form, identifying them as members. Also, Van Assche, Beunen, and Duineveld, (2012) linked performativity of organizations and their de-paradoxification:

For Luhmann, organizations are grounded in paradox, since the ultimate ground of their decisions, of their reproduction, is a product of the system itself. [...] This issue, according to Luhmann, the organization has to hide for itself, by means of what he calls de-paradoxification. Organizations create their environment of actors, competitors, causes and effects, as well as images of their internal environment, and organizational identities. All these constructs enable organizations to present themselves as entities objectively pressured by an objective environment, as it enables them to assess the impacts of their decisions in that environment as 'real' (Seidl 2005). De-paradoxification thus lies at the root of performativity in organizations, as a productive force springing from their grounding paradox. 
For health regions, this assertion means that their success (performativity in Van Assche et al., 2012) will depend on the development committed members (actors) and non-members (competitors), causes and effects, and images of their internal environment and organizational identities. These three factors could be related to what Mainil et al. (2013) termed stakeholder theory (membership), ethical theory (distribution of benefits) and branding theory (visualizing the organizational identity).

\subsection{The governance of social systems}

The development of health regions is characterized by several tensions among target groups, guiding principles, territorial scope, societal role, and ethical stance (Mainil et al., 2013; Ormond, 2013; Volgger et al., 2013). System theory helps elucidate these tensions by focusing on the ability of a social system (e.g. an organization) to make decisions under complex and divergent framework conditions (Luhmann, 2000). System theory shares a concern for complex dynamics, including non-linearity, limited predictability, continuous change, and self-organizing potential with the concept of governance. In particular, the conditions for making and implementing decisions within complex adaptive systems is a concern in systems theory as well as governance research. Furthermore, decision making is particularly relevant in embedding health regions in an increasingly complex global health system (Enserink, 2006; Martimianakis \& Hafferty, 2013).

As boundaries between public and private realms have blurred, the issue of developing and steering institutions and organizations at public-private interfaces has become salient (Post, 1987; Rhodes, 1996; Williamson, 1979). The concept of governance addresses these challenges by defining efficient and effective organizational structures to deal with ideas and flows within and across public and private systems. For instance, issues of boundary setting have been prominent in governance research and practice (Pechlaner \& Volgger, 2013; Williamson, 1999). Williamson (1999) defined the core of governance as a choice between different forms of transactions by considering their respective transaction costs. Amongst others, the political system (Rhodes, 1996), regions and innovation systems (Benz and Fürst, 2002; Braczyk, Cooke, \& Heidenreich, 1998), private companies (Aguilera \& Jackson, 2003), the tourism system (Pechlaner \& Volgger, 2013; Raich, 2006), but also health systems (Veenstra, 2002; Veenstra, \& Lomas, 1999) have been subject to scholarly discussions about governance.

Common to these different disciplinary sub-streams is the question of how to ensure collective action under conditions of diverging interests and partial goal conflicts among various stakeholders. This 
question is highly relevant in the context of health care and health regions. For instance, previous research on regional health governance indicates that health regions and cultural as well as social topographies may overlap to a significant extent and thus build on extant social capital. Specifically, health regions show a tendency to match historical regions (Veenstra, 2002). In the past, social capital has been associated with lower health inequalities (Lynch, Smith, Kaplan, \& House, 2000; Wilkinson, 1996). In sum, both governance research and systems theory underscore the importance of ties among stakeholders and the processes and structures that manage, influence, and represent these ties (e.g., programs and communication). Managing connections between stakeholders affects the costintensiveness and ethical legitimacy of decision making in health region development.

\section{Methods}

Considering the above literature in the context of the two case studies, our aim is to apply a set of indicators to health region development (taken from system theory) in an exploratory manner to assess the current state of these health regions on the path towards auto-poietic organizational system. Specifically, we consider the ability of the health region as a social system to treat citizens within the system while dealing with and possibly promoting the influx of international patients along the lines of medical and health tourism. The following research questions guide the cross-regional case studies:

1. Which stakeholders are present and what is their level of involvement?

2. How much does the local population benefit from health region development?

3. How is the health region visualized, and how honest are these portrayals?

4. To what extent is an organization program present, followed by a shared set of decisions??

5. Which personnel is expected to execute these programs?

6. What are the communication channels present in health region organization?

In the present study, a combined theoretical framework and qualitative indicators were constructed to compare regions engaged in health region development. Subsequently, two regions were observed and typified according to their status as health regions. Both regions were compared with each other on the 
qualitative indicators. As the studied regions are subject to dynamic policy, legal, social, and population processes, the methods of this study combine a variety of data sources (including survey data, ethnographies, observations and informal conversations) but are necessarily of an exploratory nature (Eisenhardt \& Graebner, 2007).

In detail, the case studies merge secondary data with two qualitative in-depth interviews with key stakeholders from each of the two regions. These interviews were conducted in April 2014, they were semi-structured and covered, among others, the above six questions. For the Autonomous Province of Bolzano-South Tyrol and its "Eastern Dolomites health region" idea, the interview was conducted with the most important promoter of the "health region" idea, a local politician and entrepreneur. Group discussions with several major stakeholders (politicians, regional development agencies, medical staff and public health management, destination managers etc.) in the project development phase (late 2011) provide a further information source. In the case of Zeeland, the interview was performed with the health innovation manager of "Economische Impuls Zeeland", the economic development agency of Zeeland, and initiator of the health region concept. Informal talks with stakeholders and participation in formal key meetings serve as complementary data material.

\section{Results}

\subsection{Typifying the Autonomous Province of Bolzano-South Tyrol}

The Autonomous Province of Bolzano-South Tyrol is the northernmost province of Italy, bordering Austria and Switzerland (see Fig. 2). In the context of this study, it can be characterized as a topographically mountainous, tourism-intensive and legally autonomous region. All three aspects highly influence the particular context of the regional health care system.

$<$ Insert here Figure 2>

Due to its high percentage of German and Ladin-speaking minority (together almost $70 \%$ of the 510,000 inhabitants, ASTAT, 2013a), the region has been granted partial autonomy from Italian national 
legislation. This autonomy partially extends to the field of health care. In this field, the Autonomous Province has so-called concurrent legislative power (Autonome Provinz Bozen-Südtirol, 2013). The national state regulates the main principles, whereas the detailed adaptation of these principles to the region is up to the regional legislation. However, from a financial point of view, the South Tyrolean health care system depends on the broader national framework conditions. Additionally, the EU directive on patient mobility (Council of the European Union, 2011; NHS European Office, 2011), when implemented by Italian national law, is expected to have notable impact on the South Tyrolean health care system. These impacts are related to the border situation as well as high tourism intensity of South Tyrol. Furthermore, from a cross-border and European context, the Euregio Tyrol-South Tyrol-Trentino (the historical region of Tyrol), which has some activity and resources in the health sector, also affects the situation (see also Brand et al., 2008).

South Tyrol is a mountain area, with $60 \%$ of the area above 1,600 meters above sea level, almost $40 \%$ declared as protected area and less than $6 \%$ of the territory suitable as potential settlement area (ASTAT, 2013a; 2013b). In contrast to several other mountain areas, by proactively promoting infrastructural development in peripheral areas, the region may avoid overall depopulation as well as internal urbanization (Ravazzoli \& Puzo, 2013).

The mountain context presents special challenges for a health care system. Distances are disproportionately high and population density relatively low (South Tyrol: 68 pers. $/ \mathrm{km}^{2}$ ). However, the mountainous landscape makes the region attractive to tourists. In 2012, the region registered 6 million arrivals and 29 million overnight stays (ASTAT, 2013a). In winter season, when skiing accidents are frequent, a substantial number of these tourists become occasional patients. Thus, tourists not travelling for medical purposes, more than half of whom are international, are a relevant group of transnational patients.

To stabilize its health care system in economically challenging times, the Autonomous Region of Bolzano-South Tyrol and in particular some parts of it (e.g. the Eastern Dolomites area) are considering synergies with its assets as a tourism destination. Discussions are going on whether a second group of transnational patients, so called medical tourists (or trans-border access seekers, Mainil, Van Loon, Dinnie, Botterill, Platenkamp, \& Meulemans, 2012), could be an interesting target group. The idea would be to use recently developed capabilities in orthopedics and surgery to attract tourists that travel specifically for medical treatment: "It is all about connecting existing infrastructures with each other, 
where the public hospital plays a particularly important role... This means ensuring primary health care in the hospital together with a smart specialization of parts of the hospital. This process would be complemented by attracting pertinent private companies to locate in this region... and finally the orientation of tourism offer in this regard" (interview with promoter health region, 2014).

Thus far, South Tyrol has been only rudimentarily positioned as a health tourism destination. Although the potential is undeniable, product development and promotion attempts have not gone beyond pointing towards wellness, sports, activities, and therapeutic landscapes (Buzinde \& Yarnal, 2012; Gesler, 1992). At the present moment (early 2014) a sustainable and integrated (and potentially transnational) health region is yet to emerge and no executable programs have been agreed upon.

Since 2007 , the regional health care system is managed by a unified regional public health agency and rests on seven public hospitals with 1,900 beds and additionally about 400 privately managed (but at least partly publicly subsidized) beds (ASTAT, 2013a). On average, the duration of stay in the seven public hospitals amounts to 6.7 days and utilization rates are around 80 per cent (ASTAT, 2013a). Beds, stays and the number of occupant days have been steadily decreasing since the year 2000 (ASTAT, 2013a).

Over the last years, rumors have been circulating that the three most peripheral public hospitals in the region would risk closure or reductions of activities. These rumors have been particularly intense for the most peripheral hospital located in the Pustertal valley $10 \mathrm{~km}$ from the Italian-Austrian border. Due to its position near the border, this hospital attracts a third group of transnational patients, namely Austrian patients crossing the border for medical treatment. These patients, which are typical in European cross-border contexts and are driven mainly by proximity compared to the nearest national public hospital, could be defined as cross-border access searchers (Mainil et al., 2012). Additionally, patients from the bordering region of Veneto are driven by similar motives and could be called crossregional access-searchers. This bordering area of the Eastern Dolomites appears particularly suitable for the development of a transnational health region, given the fact that the border crossing patient flows still occur (but are not proactively dealt with) and the hospital needs to increase or maintain its occupancy rate based on regional/national schemes (Volgger et al., 2013).

Applying the typology developed by Mitchell, Agle, and Wood (1997), the major stakeholders of the South Tyrolean health care system are illustrated in Fig. 3. Mitchell et al. (1997) distinguishes stakeholders based on three categories, power (ability to enforce a claim), legitimacy (disposing of a 
socially accepted claim) and urgency (disposing of a claim that is time critical). Many stakeholder groups of the South Tyrolean health care system have legitimate and urgent claims. However, only few have the power to enforce them. South Tyrol has been following the continental European social model in health care provision. Thus, public actors dominate the scene. Health care is considered a public good rather than a commodity and transnational patient care is seen as something potentially threatening that should be controlled. Accordingly, first discussions started among public and private stakeholders to set up a transnational health region in the Eastern Dolomites area to proactively deal with broader developments in health care. While agreeing on the basic principles (generating benefits for the local population), challenges and goals, they have not yet gone as far as developing an explicit agenda or program, stabilizing external communication channels or even dedicating personnel for operational tasks as requested by Luhmann's system theory. Rather, first attempts to develop a transnational health region in the Eastern Dolomites area have encountered resistance and are currently on hold. In this case, challenges concern mainly the transnational dimension in health region development. With this in mind, Fig. 3 illustrates that the regional government appears as a crucial actor in the regional health region development.

$<$ Insert here Figure 3>

\subsection{Typifying Zeeland}

Zeeland is a one of the 12 provinces in the Netherlands, situated at the North Sea coast, bordering Belgium. It counted in March 2014 380,681 inhabitants, which accounts for $4.3 \%$ of the Dutch population (CBS, 2014). The population density is much lower than the mean density in the Netherlands. The province of Zeeland is a typical water landscape with $39.1 \%$ water (Provincie op maat, 2007), which indicates the continuous water management necessity of this delta area. These characteristics enable Zeeland to be a nature-based area, inviting for domestic guests (7.9 million overnights in 2013) and international tourists (4 million overnights in 2013) (Provincie zeeland, 2014). However, a combination of a significant tourist population and a limited local population can lead to challenges for the province, especially in the field of health care provision. 
$<$ Insert here Figure 4>

In the Netherlands, discussions around rising health care costs are now joined by explorations onto opportunities to export health care $(D 66,2013)$. Furthermore, recent Dutch legislation will decentralize the care for the elderly and youth care to the municipalities in 2015 (Rijksoverheid, 2013), which would enable them to steer care innovation around these target groups locally. The provincial health care system of Zeeland suffers economically from an outflow of patients to Belgian border hospitals (Boffin \& Baeten, 2005) and neighbouring Dutch provinces (25\% of the patients in Zeeland go for hospital care out of the province; Provincie Zeeland, 2012). Curative care in Zeeland is mainly provided by two hospitals, ADRZ and Zorgsaam. Given the characteristics of the landscape of Zeeland (islands), the access for patients to this type of care has always been sensitive, enhanced by an emigrating and ageing population (in $201220 \%$ of the population was older than 65 years), which puts pressure on the health care system in Zeeland.

In addition to this regular supply of public curative services, new private secondary care initiatives services also occur in Zeeland (Provincie Zeeland, 2012), pinning a relation with the field of tourism. Such combinations between health and tourism could be perceived as opportunities to provide an additional supply in health-related services. In 2012 the provincial government designed a business case around medical tourism (Van Houte, 2012) with a provider, Zeeland Care, which already offered products related to medical tourism. One of their earliest activities was combining kidney dialysis and holiday taking since 2002. More recently they have been setting up private hospital settings, which could relieve waiting lists from other public hospitals, given the health insurance reimbursement system in the Netherlands. Currently, several policy levels explore if the scope could be broadened to a wider concept of a sustainable health region, supporting the health of the citizens and tourists in Zeeland, linking development strategies to the public health agenda of the provincial government.

The province of Zeeland has to cope with opposing dynamics present in health organizations and tourism providers. A tourism provider has different goals than a hospital. Specifically, tourism providers rather stake urgency claims, while hospitals tend to stake legitimacy claims. This reveals parallels between Zeeland and the Autonomous Province of Bolzano-South Tyrol. However, in Zeeland as in the Autonomous Province of Bolzano-South Tyrol, occasional synergies have been found. 'Herstellen aan de Schelde' (Zorgsaam, 2014) is a cooperation between an orthopedic unit at Zorgsaam Hospital in 
Terneuzen and the Churchill hotel. After the surgery, patients recover further in the hotel. Other new initiatives, such as the Medical Boulevard developed by ZeelandCare (PZC, 2013) on the coast of Vlissingen, the plans of the governmental health organization GGD in Zeeland to implement the blue zone typology in Zeeland (GGD, 2014) and the recent German Heilbader accreditation of two coastal municipalities Cadzand-Bad and Domburg (PZC, 2014) show that there are actors present in the province of Zeeland, engaging the boundaries of health and tourism.

A joint program of public and private stakeholders, as implied by Luhmann's social system of an organization, is still in the making. The developing concept of a health region in Zeeland could establish such a program. The economic development agency "Economische Impuls Zeeland" rates the complexity of the public professional field as being represented by different involved thematic policy levels at the regional state and community level. It was also indicated that this health regionalism should be driven by a triple helix structure (government, entrepreneurs and knowledge institutes). Furthermore, the civil society (i.e. patient advocacy organizations/elderly boards) should not be left out of this development (interview with program manager Innovative Care, 2014). To tackle this complexity, we suggest an alternative sustainable model for health region development for Zeeland (see Fig. 5).

$<$ Insert here Figure 5>

The model is based on a shared responsibility of government, producers of products and services and citizens towards the environment of Zeeland. Important is also the responsibility of the regional and local policy levels to guard that the services, which are produced, are in line with the environment and with an effect on the health of its citizens and tourists. The economic development agency "Economische Impuls Zeeland" sees tourism as an enabler for creating additional health services and products for the population in Zeeland. In this citizen perspective, other characteristics for a health region consist of healthy food and movement health promotion and mental wellbeing, all in favor of the citizens and tourists in Zeeland (interview with program manager Innovative Care, 2014). The province is more known and organized as a tourism destination, rather than a health region where health care is bound to excel. However, in view of an emigrating and ageing population and sensitive landscape-based 
supply of health care services, a carefully designed program of health region development could combine the strengths of both sectors.

\subsection{Comparison: Region of Zeeland versus Region of South Tyrol}

To compare Zeeland to South Tyrol, we refer to the research questions. Table 1 visualizes the comparison between Zeeland and the Autonomous Province of Bolzano-South Tyrol, and compares them to an idealized and fully developed health region from the system theory view. This comparison reveals restrictions in the health region development processes inherent to the development of an organization structure. First discussions, involving private and public stakeholders, around health region development take place in both regions. However, the development towards specific organization programs, executing personnel and external communication channels is still uncertain.

$<$ Insert here Table 1>

\section{Discussion}

The case of the Eastern Dolomites health region idea in the Autonomous Province of Bolzano-South Tyrol illustrates that health region development is a politically relevant and sensitive issue. In spite of economic benefits, a general political willingness to adapt to changing environments and obvious interregional synergies, political actors on some levels may hesitate in supporting transnational health region development. In the concrete case of the Eastern Dolomites, in spite of broad local support and support of the Euregio, the initial transnational health region project was paused (mainly due to issues concerning the transnational dimension). This development indicates that a transformation in the „imagined geography of care“ (Ormond, 2010) may have widespread political, administrative and cultural implications. However, as the interviewed promoter of the project argues, the programmatic discussions and awareness-raising initiatives are continuing. For instance, a series of conferences on specific topics take place, which are however pertinent to the overall idea of a health region. Indirectly, further awareness raising and communication is done towards tourists: The communicated clean air and attractive ("therapeutic") landscape provide a basis for developing and communicating a health region (at least) to the target group of tourists (interview with the promoter of health region, 2014). 
In the case of the province of Zeeland there is an early stage positive attitude present to engage in health region development, decisions to engage further toward the conceptual formation of an organizational structure, need to be preluded by further knowledge development and evidence. "Economische Impuls Zeeland" refers to this knowledge development by adding that it should first be proven that Zeeland offers a healthy environment, before it can be stated or developed as a health region (interview with program manager Innovative care, 2014). With respect to the importance of a healthy environment for the development of a health region that is attractive to residents and tourists, we may sense similar thoughts and dynamics in both case study regions. Additionally, in both case studies this relates to the complexity of involving stakeholders and developing shared decision sets.

By applying Luhmann's system theory $(1992,2000)$ to the health region development, a theoretical benchmark of auto-poietic social systems (in the specific case organizations) can be established. According to Luhmann, a health region could be classified as auto-poietic, i.e. as self-reinforcing, stable and self-referential, when a decision-making process is set in place which is characterized by a common culture, programs, decision makers, and communication channels.

According to Luhmann $(1992,2000)$, decisions play a central role in organizations. To understand health regions as auto-poietic systems, it is necessary to illustrate the role of decisions. If we follow Luhmann's argument, then health regions can only work as auto-poietic systems if they are based on decisions that empower the region as a whole in future decision making (Luhmann, 1992). Hence, a certain decision autonomy is required to establish self-reinforcing, sustainable health regions. In the case of South Tyrol, explicit decisions concerning the establishment of a cross-border health region have not been made so far. However, project-based attempts have already offered a field for experimenting with decision making in the context of a health region. The reluctance of the powerful actors (mainly the regional government) to take an immediate decision on transnational health region development implied a postponement of change and a perpetuation of the existing health care system. However, promoters at different levels are still actively engaged in promoting a slightly modified and maybe in a first stage less ambitious but then more dynamic idea of the health region "Eastern Dolomites" (interview with the promoter of health region, 2014). In the case of Zeeland, an initial argumentation set in the direction of a health region is being processed, but it is a fragile process. The regional government of Zeeland can learn from other EU examples, such as the "Eastern Dolomites" experience in the Autonomous Province of Bolzano-South Tyrol, about challenges in this process. 
Cascades of decisions can be facilitated by the existence of a common culture as well as programs (Luhmann, 2000). While a common identity is widespread in the Eastern Dolomites, programs are still in their infancy and mainly driven by European Union initiatives. Among them figure Interreg projects and Euregio initiatives. Besides programs, the existence of decision-makers and their implementation (i.e. personnel) and communication channels are important decision premises (Luhmann, 1992, 2000). However, in the South Tyrolean context, both communication channels and personnel are still connected with the traditional health care system or (more importantly) with the tourism system (see Fig. 6). In reference to Fig. 6 in the context of the Zeeland region, we can conclude that a conceptual common culture is being developed at present (early 2014), but that programs, personnel and communication channels are still uncertain to develop at all.

Health care is an important governance mechanism and offers leverages for political agency. By altering an established geography of care, political and cultural balances might change direction. Three major challenges could appear (see also Mainil et al., 2013; Pforr et al., 2011):

(1) from a territorial perspective, the issue of place-making at the interface between the local and the global and/or in the light of established administrative as well as political boundaries;

(2) from a functional and resource-based perspective, leadership at the interface between private and public;

(3) from a relational perspective, the governance at the interface between a hierarchicalbureaucratic and a market-based steering mechanism.

Setting up a health region is connected to processes of place making and the development of regional identities. Not accidentally, transnational health regions in the European context tend to develop within frameworks of historical regions (that today might be separated by national frontiers; Veenstra, 2002). The same holds true in the South Tyrolean case. Here, the historical region of Tyrol, represented today by the Euregio, sets relevant frameworks for regional identities that could be enacted through a health region.

Despite political challenges, we assert that from a functional point of view, regional identities can facilitate health region development. A health region with its place-making dynamics, paired with a preexisting regional identity that coincides with the health region, may mutually reinforce and stabilize. In the case of Zeeland, the interface function between private and public and the interface between a 
hierarchical-bureaucratic and a market-based steering mechanism are of critical importance. The question is if public and private actors will be able to share one joint strategic program, finding a rhythm which interludes between bureaucratic and market-based steering mechanisms. The adaptive capacity of the regional government is crucial in this context.

\author{
$<$ Insert here Figure 6>
}

Based on Luhmann $(1992,2000)$, we can make a step further and pose the question of how to steer and govern such a health region. An auto-poietic system shows tendencies of self-governance limiting the opportunities for other systems to enter its internal mechanisms of checks and balances. Therefore, from a theoretical point of view, governance systems that are capable of balancing the various stakeholder interests in decision making hold promise. For example, cooperatives might qualify as a suitable organizational form (Brand \& Michelsen, 2012; Mooney \& Gray, 2002; Volgger et al., 2013; Volgger \& Pechlaner, forthcoming) for auto-poietic transnational health regions under conditions of a retreating welfare state.

\title{
6 Conclusions and prospect
}

Luhmann provided a theoretical framework of social systems that the present study applied to the concept of a health region. An organization as a social system consists of decisions, programs, personnel and communication channels. These constituents could be related to health regions as organizations, with sets of stakeholders, linkages and benefits for local populations, and visualizations of such a health region. In the practice of the EU, efforts to develop existing regions into health regions, at the moment (early 2014) appear less successful than they could be.

Our exploratory study made a comparison between two regions in the EU (the Autonomous Province of Bolzano-South Tyrol, Italy, and its "Eastern Dolomites" health region idea, and the region of Zeeland, Netherlands) and applied a system theory perspective to these cases. Based on the benchmark offered by this perspective, where fully developed health regions can be viewed as auto-poietic systems, the study indicates that the path towards becoming a health region in full effect is long and stony, full of 
political, legal and economic hurdles. Indeed, both analyzed regions cannot yet be considered as fully developed health regions. Both are stuck on their way to becoming a health region, on different but at the same time similar stages: In both cases, developing and generating acceptance for a common vision and its first operationalization in a common program are initial steps but appear to be not easy ones. The cases indicate that they may require multiple attempts before accomplishment and before it is possible to proceed with further steps on the level of personnel and communication of health regions. However, in both cases some actors continue to push the vision despite difficulties. From the employed system perspective it seems promising and crucial to investigate promoters and inhibitors as well as levers and obstacles in health region development step by step.

It seems quite clear that different stakeholder groups should be integrated in the development of a health region, possibly resulting in shared objectives with regards to governance and leadership. We reviewed empirical evidence concerning the Autonomous Province of Bolzano-South Tyrol, where some actors have still some doubts about the feasibility of creating transnational health regions (concerns relate mainly to the transnational dimension). Other actors continue to push the idea forward. In the region of Zeeland, governmental attitude to the process is still positively grass-rooting (facilitated by the missing transnational hurdles), but further conceptual development will have to prove its usefulness.

The full engagement of regional governments in this process and the particular challenges involved in overcoming national boundaries appear to be critical factors. If such processes become self-sustaining in Zeeland and South Tyrol remains to be seen. Therefore, further research could be focused on comparing more regions and their policies in becoming or not becoming a health region. Interesting topics concerning levers and barriers as well as relevant questions for further research emerge on the micro-, meso- and macro-levels. On the micro-level in particular cooperatives provide a promising opportunity to balance different interests and expectations in health region development and thus require further research. On the meso-level, the relation between sub-national or transnational health region pose challenges in real political and identity terms to the nation state, which deserve detailed investigation. Finally, on the macro-level it would be valuable to explore the relationship between the EU Directive on the application of patient rights and health region development. It is not yet known whether this EU legislation empowers health regions or reinforces the traditional national health care systems. 


\section{References}

Aguilera, R. V., \& Jackson, G. (2003). The cross-national diversity of corporate governance: Dimensions and determinants. Academy of Management Review, 28(3), 447-465.

Anon. (2008). Ten Theses on regional health and Wealth. Regions for health Network. WHO regional Office for Europe.

ASTAT (Autonome Provinz Bozen - Südtirol Landesinstitut für Statistik) (2013a). Statistisches Jahrbuch 2013. Bozen.

ASTAT (Autonome Provinz Bozen - Südtirol Landesinstitut für Statistik) (2013b). Dauersiedlungsgebiet in Südtirol 2012. Bozen.

Autonome Provinz Bozen - Südtirol (2013). Südtirol Handbuch 2013. Bozen.

Benz, A., \& Fürst, D. (2002). Policy learning in regional networks. European Urban and Regional Studies, 9(1), 21-35.

Boffin, N., \& Baeten, R. (2005). Dutch Patients Evaluate Contracted Care in Belgian Hospitals: Results of a Mail Survey. Observatoire social européen (OSE), Bruxelles.

Booi, T. (2007). Vakantie met zorg in Zeeland: Marktverkenning naar economische kansen voor vakantie met zorg. Kamer van Koophandel voor zeeland.

Braczyk, H. J., Cooke, P., \& Heidenreich, M. (Eds.) (1998). Regional innovation systems: the role of governances in a globalized world. London: UCL Press.

Brand, H., Hollederer, A., Wolf, U., \& Brand, A. (2008). Cross-border health activities in the Euregios: Good practice for better health. Health Policy, 86, 245-254.

Brand, H., \& Michelsen, K. (2012). Collaborative governance: The example of health conferences. In D.V. McQueen, M. Wismar, V. Lin, C. M. Jones \& M. Davies (Eds.), Intersectoral governance for health in all policies: Structures, actions and experiences (pp. 165-184). Copenhagen: WHO Office for Europe on behalf of the European Observatory on Health Systems and Policies.

Buzinde, C.N., \& Yarnal, C. (2012). Therapeutic landscapes and postcolonial theory: a theoretical approach to medical tourism. Social Science \& Medicine, 74(5), 783-7.

Centraal Bureau voor de Statistiek (2008). Provincie op Maat: zeeland. Den Haag/Heerlen, 58p.

Connell, J. (2006). Medical tourism: Sea, sun, sand and... surgery. Tourism Management, 27(6), 10931100.

Council of the European Union (2011). Directive on cross-border health care adopted (press release). 
Courpasson, D. \& Clegg, S. (2006). Dissolving Iron Cage?: Tocqueville Michels Bureaucracy and the Perpetuation of Elite Power. Organization, 13 (3).

Crooks, V. A., Turner, L., Snyder, J., Johnston, R., \& Kingsbury, P. (2011). Promoting medical tourism to India: Messages, images, and the marketing of international patient travel. Social Science \& Medicine, 72(5), 726-732.

Decoster, C. (2012). Jaarverslag Observatorium Patienten mobiliteit. 64p. accessed online 21/04/2014 https://www.riziv.fgov.be/information/nl/studies/study67/pdf/rapport.pd

Eisenhardt, K.M., \& Graebner, M.E. (2007). Theory building from cases: opportunities and challenges. Academy of Management Journal, 50(1), 25-32.

Enserink, M. (2006). H5N1 moves into Africa, European Union, deepening global crisis. Science, 311(5763), 932-932.

Gesler, W.M. (1992): Therapeutic landscapes: Medical issues in light of the new cultural geography. Social Science and Medicine, 34(7), 735-746.

Glinos, I.A., Baeten, R., Helbe, M., \& Maarse, H. (2010). A typology of cross-border patient mobility. Health and Place, 16(6), 1145-1155.

Glinos, I.A. (2012). Worrying about the wrong thing: Patient mobility versus mobility of health care professionals. Journal of Health Services Research and Policy, 17(4), 254-256.

Glinos, I.A., \& Wismar, M. (Eds.) (2013). Hospitals and borders: Seven case studies on cross-border collaboration and health system interactions. United Kingdom, World Health Organization.

Luhmann, N. (1992). Organisation. In W. Küpper, \& G. Ortmann (Eds.), Rationalität, Macht Und Spiele in Organisationen (pp. 165-85). Opladen: Westdeutscher Verlag.

Luhmann, N. (2000). Organisation und Entscheidung. Opladen: Westdeutscher Verlag.

Luhman, J.T., \& Cunliffe, A.L. (2013). Key concepts in Organization theory. London: Sage, 182 p.

Lynch, J.W., Smith, G.D., Kaplan, G.A., \& House, J.S. (2000). Income inequality and mortality: importance to health of individual income, psychosocial environment, or material conditions. BMJ: British Medical Journal, 320, 1200-1204.

Mainil, T., Dinnie, K., Botterill, D., Platenkamp, V., van Loon, F., \& Meulemans, H. (2013). Towards a model of sustainable health destination management based on health regions. In D. Botterill, G. Pennings, \& T. Mainil (Eds.), Medical tourism and transnational health care (pp. 240-255). Palgrave MacMillan. 
Mainil, T., Van Loon, F., Dinnie, K., Botterill, D., Platenkamp, V., \& Meulemans, H. (2012). Transnational health care: From a global terminology towards transnational health region development. Health Policy, 108(1), 37-44.

Martínez Álvarez, M., Chanda, R. \& Smith, R.D. (2011). The potential for bi-lateral agreements in medical tourism: A qualitative study of stakeholder perspectives from the UK and India. Globalization \& Health, May 3;7:11. doi: 10.1186/1744-8603-7-11.

Martimianakis, M.A.T., \& Hafferty, F.W. (2013). The world as the new local clinic: A critical analysis of three discourses of global medical competency. Social Science \& Medicine, 87, 31-38.

Mitchell, R.K., Agle, B.R., \& Wood, D.J. (1997). Toward a theory of stakeholder identification and salience: Defining the principle of who and what really counts. Academy of Management Review, 22(4), 853-886.

Mooney, P., \& Gray, T.W. (2002). Cooperative conversion and restructuring in theory and practice. United States Department of Agriculture. Research Report 185.

Nassehi, A. (2005). Organizations as decision machines: Niklas Luhmann's theory of organized social systems. The Sociological Review, 53 (s1), 178-191.

NHS European Office (2011). Patient choice beyond borders: Implications of the EU Directive on crossborder healthcare for NHS commissioners and providers. Briefing 7, pp. 1-8.

Ormond, M. (2010). International medical travel and the politics of therapeutic place-making in Malaysia. Doctoral dissertation, University of St. Andrews (Scotland, UK), 2010.

Ormond, M. (2013). Neoliberal governance and international medical travel in Malaysia. London: Routledge.

Pechlaner, H., \& Volgger, M. (2013). Towards a comprehensive view of tourism governance: relationships between the corporate governance of tourism service firms and territorial governance. International Journal of Globalisation and Small Business, 5(1), 3-19.

Pforr, C., Pechlaner, H., Locher, C., \& Jochmann, J. (2011). Health regions as tourism destinations: A new approach to regional development? Paper presented at the International Conference on Tourism, ICOT 2011, 27th - 30th April 2011, Rhodes Island, Greece.

Pocock, N.S., \& Hong Phua, K. (2011). Medical tourism and policy implications for health systems: a conceptual framework from a comparative study of Thailand, Singapore and Malaysia. Globalization and Health, 7(12), 1-12.

Post, R. C. (1987). Between Governance and Management: The History and Theory of the Public Forum. Faculty Scholarship Series. Paper 214. (accessible online:

http://digitalcommons.law.yale.edu/fss_papers/214) 
Provincie Zeeland (2011). Kiezen of verliezen. Visie op de ontwikkeling van de Zeeuwse ziekenhuiszorg. 29 p.

Raich, F. (2006). Governance räumlicher Wettbewerbseinheiten: ein Ansatz für die TourismusDestination. Wiesbaden: DUV.

Ravazzoli, E., \& Puzo, Q. (2013). Population growth rate, average annual 2001-2010. EURAC research. Available from:

http://www.eurac.edu/en/research/institutes/regionaldevelopment/Projects/PublishingImages/Erweite rte\%20Alpen.jpg

Rhodes, R.A.W. (1996). The new governance: governing without government. Political studies, 44(4), 652-667.

Rosenthal, E. (2013). The growing popularity of having surgery overseas. New York Times, August, 6.

Schoeneborn, D. (2011). Organization as Communication: a Luhmannian Perspective. Management Communication Quarterly, 25(4), 663-689.

Seidl, D. (2004). Luhmann's theory of autopoietic social systems. Business Research Paper, 2004(2), LMU Ludwig-Maximilians-Universität München, Munich School of Management.

Seidl, D. (2005). Organizational identity and self-transformation: An autopoietic perspective. Aldershot: Ashgate.

Seidl, D., \& Becker, K.H. (2006). Organizations as Distinction Generating and Processing Systems: Niklas Luhmann's contribution to organization studies. Organization, 13(1), 9-35.

Sels, L. (1997). Organisaties, wat zijn dat? Een Luhmanniaanse kijk. In R. Laermans (Ed.), Sociale Systemen bestaan: Een kennismaking met het werk van Niklas Luhmann (pp. 197-215). Acco Leuven.

Smith, R. D., Chanda, R., \& Tangcharoensathien, V. (2009). Trade in health-related services. The Lancet, 373(9663), 593-601.

Van Assche, K., Beunen, R., \& Duineveld, M. (2012). Performing success and failure in governance: Dutch planning experiences. Public Administration, 90(3), 567-581.

Van Houte, P. (2012). Economische Agenda 2013-2015: Voor een duurzame economische ontwikkeling van Zeeland. Provincie Zeeland.

Veenstra, G. (2002). Social capital and health (plus wealth, income inequality and regional health governance). Social Science \& Medicine, 54(6), 849-868.

Veenstra, G., \& Lomas, J. (1999). Home is where the governing is: social capital and regional health governance. Health \& Place, 5(1), 1-12. 
Volgger, M., \& Pechlaner, H. (forthcoming). Kooperative Governance: Genossenschaften zwischen Standort- und Betriebsmanagement. In J. Laurinkari, R. Schediwy, \& Blisse, H. (Eds.), Festschrift Johann Brazda.

Volgger, M., Pechlaner, H., \& Pforr, C. (2013). Governance of transnational health regions: Realizing potentials for health tourism and regional development. Paper presented at the 'Transnational Health Care: A cross-border symposium', 20-21 June and 24-25 June 2013, Wageningen (NL), Leeds (UK).

Webb, J. (2004 Organizations, self-identities and the New Economy. Sociology, 38(4): 719-738.

Whittaker, A. (2008). Pleasure and pain: Medical travel in Asia. Global Public Health, 3(3), 271-290.

Wiener, J. (1999). Globalization and the harmonization of law. New York: Pinter.

Wilkinson, R. (1996). Unhealthy societies: The afflictions of inequality. London: Routledge.

Williamson, O. E. (1979). Transaction-cost economics: the governance of contractual relations. Journal of law and economics, 22(2), 233-261.

Williamson, O. E. (1999). Strategy research: governance and competence perspectives. Strategic Management Journal, 20, 1087-1108.

\section{Web references:}

Bavarian State Ministry of the Environment and Public Health (2014). http://www.state-ofhealth.de/english/index.htm

Centraal Bureau voor de Statistiek (2014). http://www.cbs.nl/nl-

$\mathrm{NL} / \mathrm{menu} /$ themas/bevolking/nieuws/default.htm

D66 (2013). https://www.d66.nl/actueel/zorgtop-export-nederlandse-zorg/

GGD (2014). http://www.ggdkennisnet.nl/nieuws?tag=blue+zones

Provincie Zeeland (2014). https://www.zeeland.nl/toerisme_recreatie/cijfers/

PZC (2013). Zorgboulevard in Zeevaartschool Vlissingen. March, 20. http://www.pzc.nl/regio/zeeuwsnieuws/zorgboulevard-in-zeevaartschool-vlissingen-1.3724830

PZC (2014). Cadzand-bad en Domburg zijn officieel badplaats.. March, 7.

http://www.pzc.nl/regio/zeeuws-nieuws/cadzand-bad-en-domburg-zijn-officieel-badplaats-1.4254888

Rijksoverheid (2013). http://www.rijksoverheid.nl/onderwerpen/gemeenten/decentralisatie-vanoverheidstaken-naar-gemeenten

ScanBalt BioRegion (2014). www.Scanbalt.org 
Scanbalt health region (2014). http://www.scanbalt.org/projects/scanbalt+health+region Tourismus NRW e.V. (2014). http://www.nrw-tourism.com/health/

Zorgsaam (2014):. http://www.zorgsaam.org/orthopedie/herstellen-aan-de-schelde/ 


\begin{tabular}{|c|c|c|c|}
\hline & $\begin{array}{l}\text { Eastern Dolomites health } \\
\text { region in South } \\
\text { Tyrol/Bolzano (IT) }\end{array}$ & Zeeland (NL) & $\begin{array}{l}\text { Idealized and } \\
\text { fully developed } \\
\text { health region }\end{array}$ \\
\hline $\begin{array}{l}\text { 1.Involvement of } \\
\text { stakeholders }\end{array}$ & $\begin{array}{l}\text { Lead in the discussion is } \\
\text { taken over by public } \\
\text { stakeholders. Private } \\
\text { stakeholders are interested, } \\
\text { but no common } \\
\text { organizational structure yet }\end{array}$ & $\begin{array}{l}\text { Motivated public and } \\
\text { private stakeholders } \\
\text { present, but no } \\
\text { strategic involvement } \\
\text { yet }\end{array}$ & $\begin{array}{l}\text { Broad } \\
\text { organizational } \\
\text { involvement of } \\
\text { different } \\
\text { stakeholder } \\
\text { groups }\end{array}$ \\
\hline $\begin{array}{l}\text { 2.Benefits for local } \\
\text { population }\end{array}$ & $\begin{array}{l}\text { Goal of health region } \\
\text { concerns the maintenance } \\
\text { of high quality health care } \\
\text { for the local population in } \\
\text { peripheral areas }\end{array}$ & $\begin{array}{l}\text { Goal of health region } \\
\text { development is to } \\
\text { support employment } \\
\text { and healthy lifestyle of } \\
\text { local population. }\end{array}$ & $\begin{array}{l}\text { Goal is to } \\
\text { ensure high } \\
\text { quality health } \\
\text { care for all local } \\
\text { residents and } \\
\text { tourists }\end{array}$ \\
\hline $\begin{array}{l}\text { 3.Visualization of the } \\
\text { health region }\end{array}$ & $\begin{array}{l}\text { The region is visualized as a } \\
\text { tourism region. No } \\
\text { visualization as a health } \\
\text { region exists yet, but first } \\
\text { discussions initiated. }\end{array}$ & $\begin{array}{l}\text { The region is visualized } \\
\text { as a tourism region. No } \\
\text { visualization as a } \\
\text { health region exists } \\
\text { yet. }\end{array}$ & $\begin{array}{l}\text { Visualization as } \\
\text { health region } \\
\text { that serves both } \\
\text { residents' and } \\
\text { tourists' } \\
\text { purposes }\end{array}$ \\
\hline $\begin{array}{l}\text { 4. Organization } \\
\text { program } \\
\text { present? }\end{array}$ & $\begin{array}{l}\text { No organization program } \\
\text { yet, first discussions and } \\
\text { reflections ongoing }\end{array}$ & Not yet present & $\begin{array}{l}\text { Specific } \\
\text { organization } \\
\text { with program }\end{array}$ \\
\hline $\begin{array}{l}\text { 5. Executing } \\
\text { Personnel }\end{array}$ & $\begin{array}{l}\text { Limited personnel involved, } \\
\text { for conceptual reflections }\end{array}$ & Not yet present & $\begin{array}{l}\text { Specific } \\
\text { personnel }\end{array}$ \\
\hline $\begin{array}{l}\text { 6.Communication } \\
\text { channels } \\
\text { present }\end{array}$ & Strictly internal & Not yet present & $\begin{array}{l}\text { Specific internal } \\
\text { and external } \\
\text { communication } \\
\text { channels }\end{array}$ \\
\hline
\end{tabular}

Table 1: Comparison in health region development between the regions of South Tyrol/Bolzano (in particular the Eastern Dolomites area), Zeeland and an idealized/fully developed health region 
FIGURES

Figure 1: A selection of theories that can be combined with a system theory view on health regions

\section{Health region as a social system: An organization}

Stakeholder
theory
Government,
research and
education,
health prevention,
medical technology,
hospitals and primary
health care,
health tourism
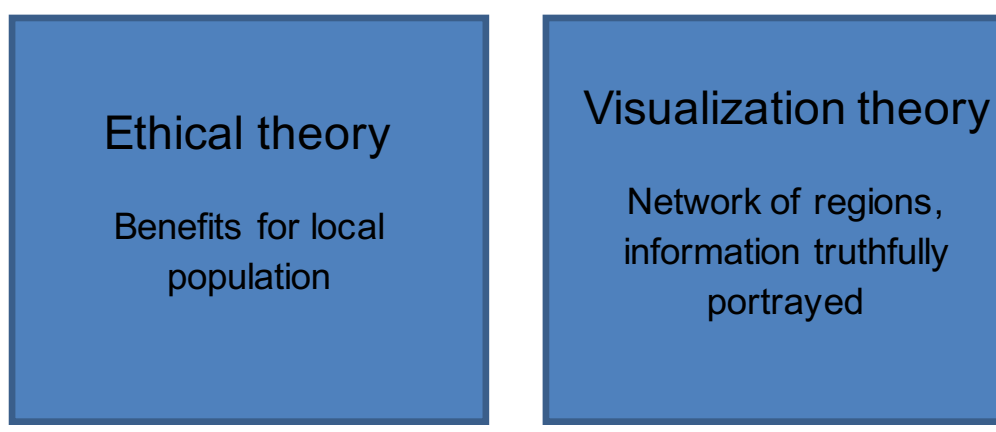

Network of regions, information truthfully portrayed

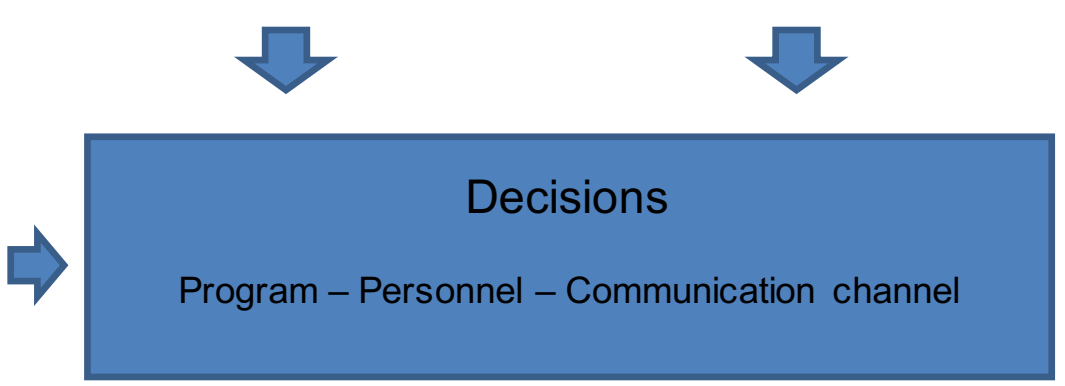


Figure 2: The Autonomous Province of Bolzano-South Tyrol

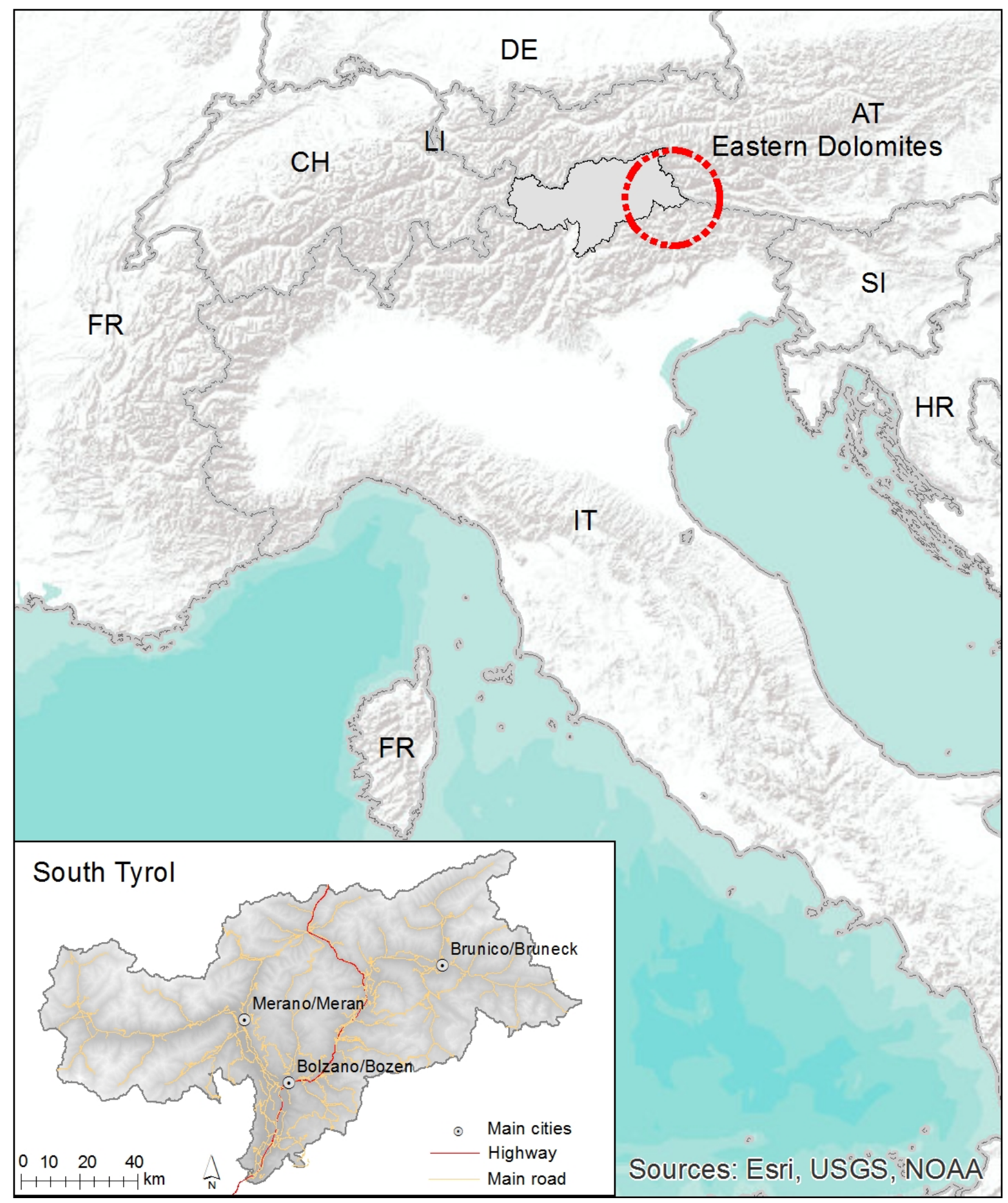


Figure 3: Major stakeholders of the South Tyrolean health care system (based on the typology developed by Mitchell et al., 1997)

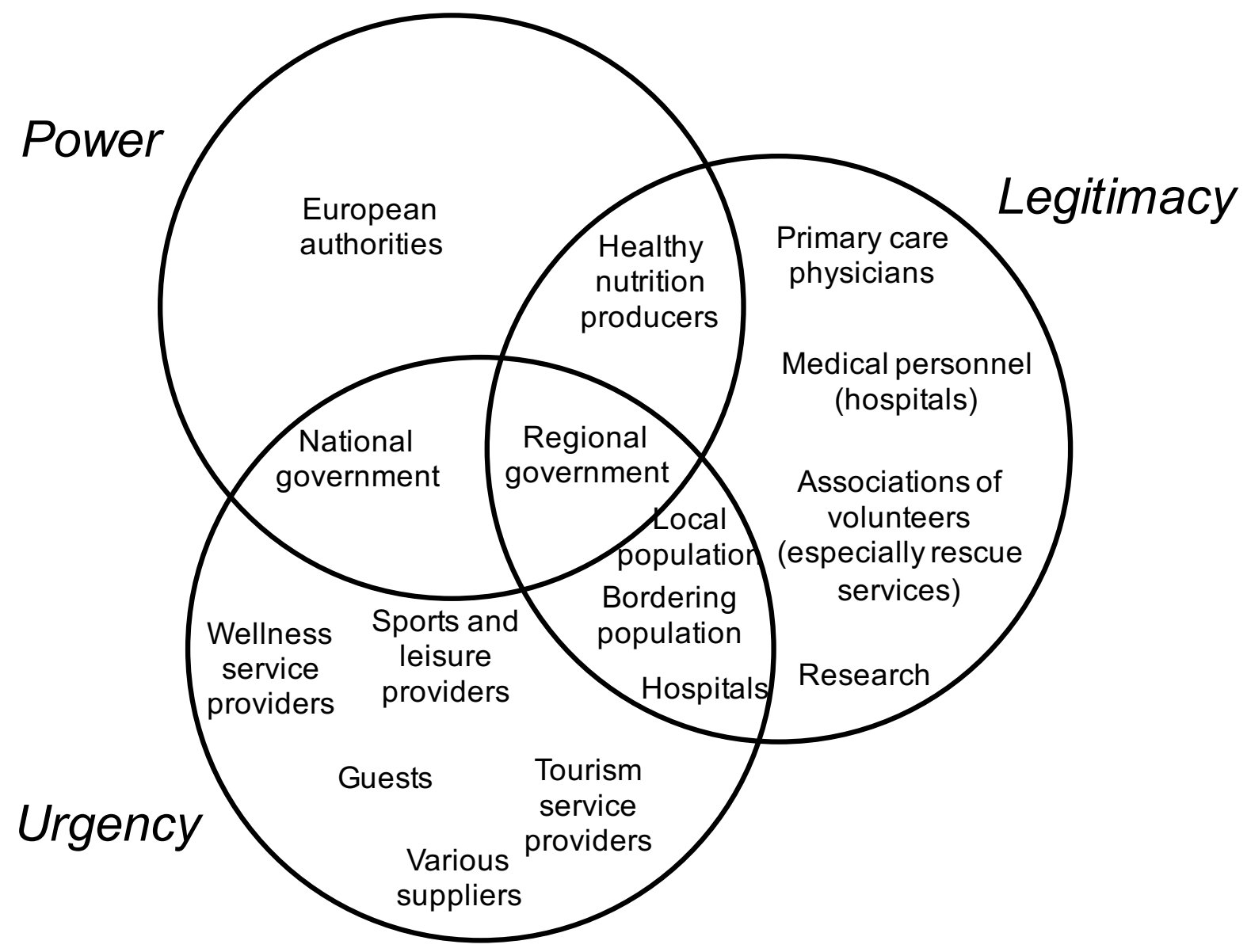


Figure 4: The Dutch Province of Zeeland

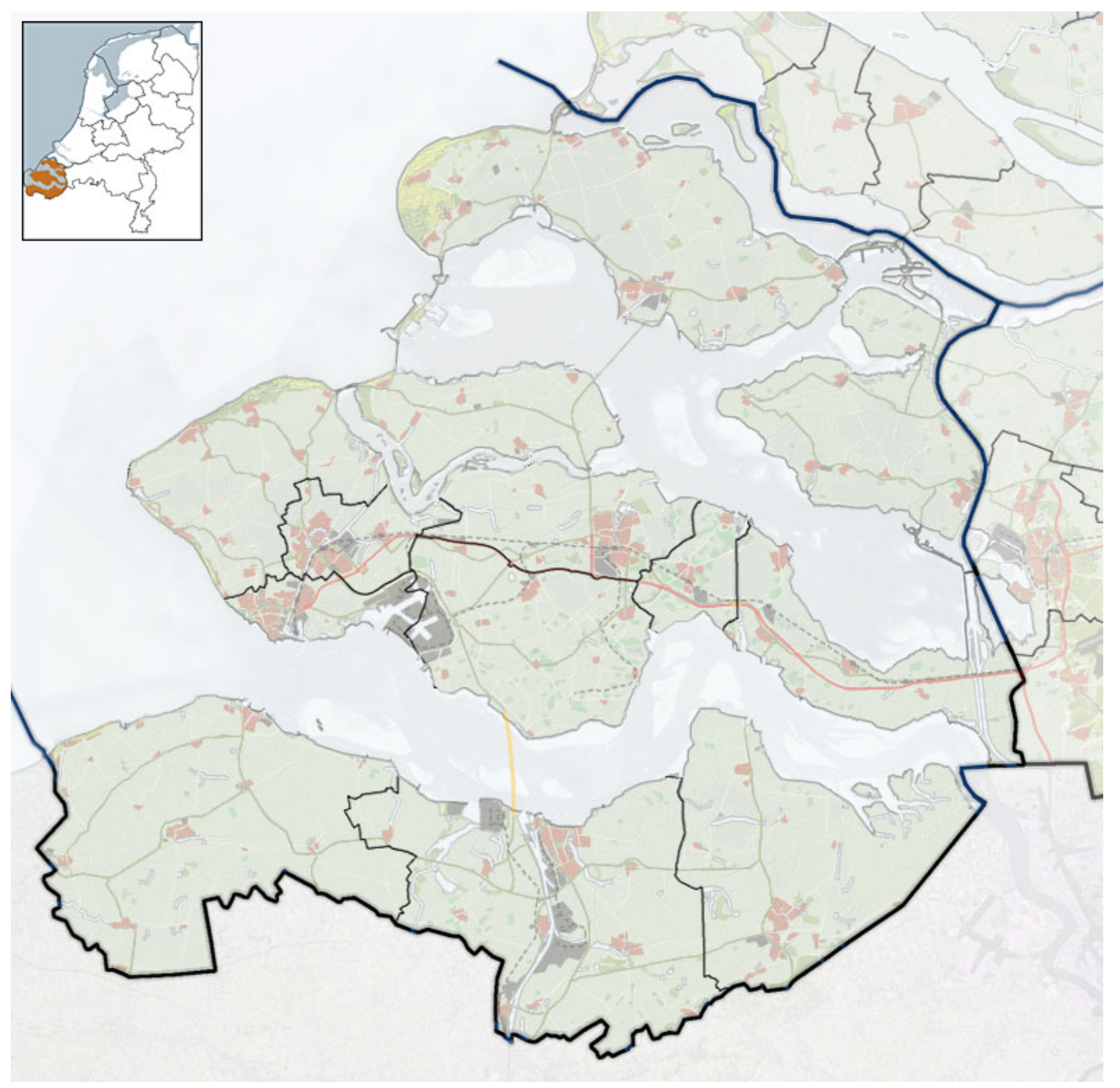


Figure 5: A health region model for the province of Zeeland

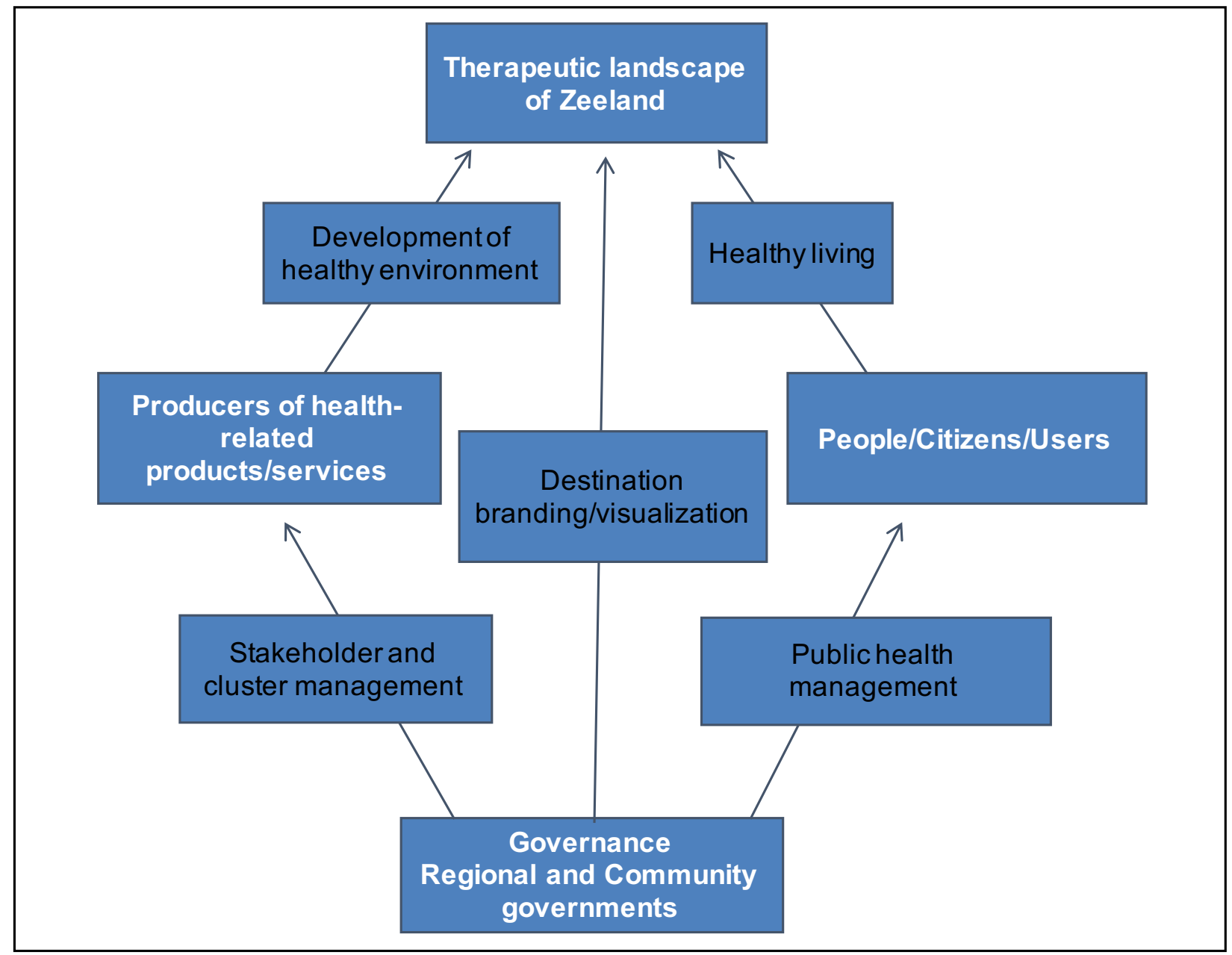


Figure 6: Comparison of the South Tyrolean health care systems from a system theory point of view

Traditional health care

system

\section{Common culture}

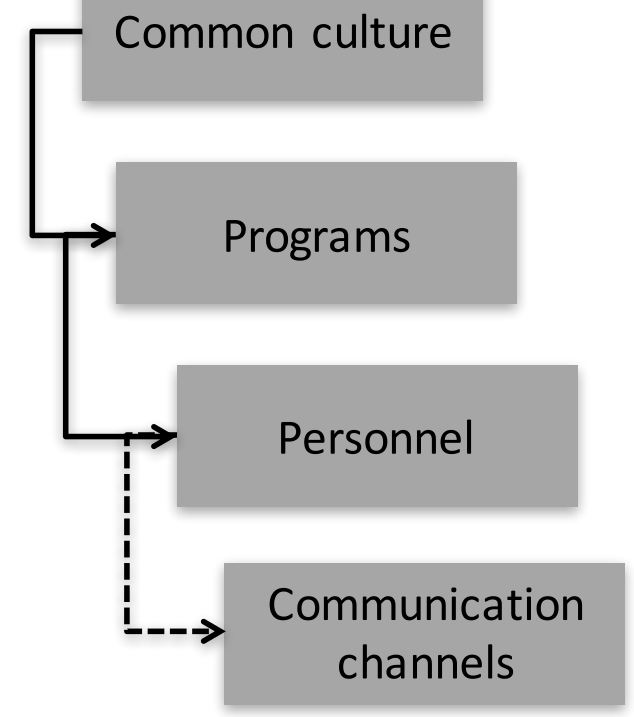

Health region development (Eastern Dolomites \& Zeeland)

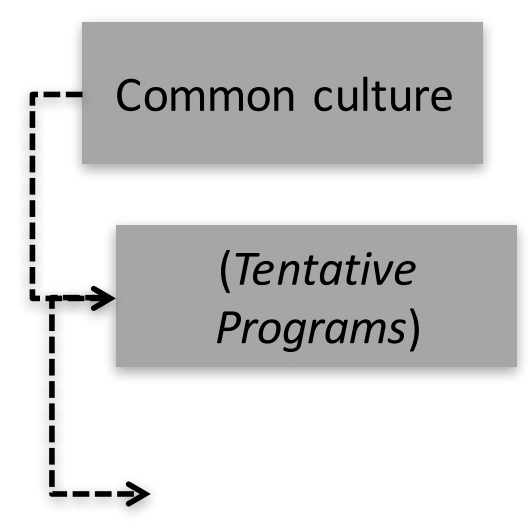

